$\xi=-1$

\title{
Regulation of the Dynamics of Creating High-Tech Products
}

\author{
Aleksandr Batkovskiy ${ }^{1}$, Aleksandr Leonov ${ }^{2}$, Aleksey Pronin $^{3}$, Alexander Chursin $^{4}$, Evgeniy Nesterov $^{5}$ \\ ${ }^{1}$ Joint Stock "Electronica" Company (The Central Research Institute of Economy, Management and Information Systems), Cosmonaut \\ Volkov street, 12, Moscow, 127299, Russia \\ ${ }^{2}$ Moscow Aviation Institute (National Research University), Volokolamskoe highway, 4, Moscow, 125993, Russia \\ ${ }^{3}$ Moscow Technological University (MIREA), Vernadsky avenue, 78 Moscow, 119454, Russia. \\ ${ }^{4}$ RUDN University, Miklukho-Maklaya street, 6, Moscow, 117198, Russia \\ ${ }^{5}$ JSC "Russian space systems", Aviamotornaya street, 53, Moscow, 111250, Russia
}

\begin{abstract}
The existing models for regulating the dynamics of the creation of science-intensive products are very fragmented; they are based on various initial data and do not allow giving a comprehensive assessment of the feasibility of RandD for the creation of science-intensive products within a given time, especially in risk.

Financial and economic risk; scientific, industrial and technological risk. Taking into account these types of risk, we introduce a methodical tool. This is a complex model for regulating economic dynamics designed for a probabilistic and cost description of the dynamics and results of the creation of science-intensive products.

The model provides a complex tech-economic evaluation of projects to develop high-tech products in risk. This model has a universal character and can be used in all branches of economics of a technologically developed country. In practice, this complex model can be useful at the stage of selection of competing organizations designs with the purpose of evaluating their capacity to implement projects, as well as at the stage of adjusting the funding plan and cost estimates for the creation of science-intensive products.

This model may be used in planning bodies to assess the capabilities of design organizations in the implementation of orders for the creation of science-intensive products.
\end{abstract}

Keywords: Regulation; Dynamics; Complex Models; Science-Intensive Products; High-Tech Products

\section{Introduction}

In the context of high volatility of markets of mineral raw resources, system forming nature of the mineral resources sector in the national economy, the forecast of developing sectors and companies of the mineral resources (mining) sector becomes an important and at the same time difficult task. In this context the most adequate tool to forecast the development of sectors and companies of the mineral resources sector is scenario planning.

Scenarios of developing mineral resources markets and mineral resources sector as a whole make it possible to choose the most probable basic strategy of the state in the area of natural resources management or sub-area of the mineral resources sector and to form a promising plan or a comprehensive program of its longterm development. Such grand scenarios of developing markets and the complex make it possible to efficiently and reasonably develop companies that can develop their own development scenarios based on general benchmarks of the sector development. Scenario planning allows managers of all levels to adapt to various variants of developing macro-economic parameters and events on the markets of mineral raw materials, and to have certain solutions and alternative variants of development.

The most important component of modern science-intensive production is high-tech products, which are products created using new knowledge and technologies $[1,2]$. The main stages of creating a high-tech product $[3,4,5$ :

- Research, Development, and Engineering (RDE);

- development of technical specifications;
- feasibility study;

- both the Front End Engineering Design and the Design and Development (D and D);

- prototyping and testing;

- preparing working construction documentation (WCD) and correcting it after tests.

However, it seems possible to make a predictive assessment of the results at each stage in the creation of high-tech products and the entire project as a whole only at a probabilistic level, since this process has a very high degree of uncertainty due to the impact of multiple random factors. To achieve with a certain probability the required results at each of the above stages, the support of hightech production with personnel, materials, information and financial resources plays an important role. The organization of work, the intellectual and professional level of employees and other intangible resources also matter. Each of these resources contributes to the expected outcome of the project, thus improving, or, vice versa, lowering the probability of the release. The identification and study of the patterns of time-honored economic processes of creating high-tech production, taking into account the aforementioned risk factors for the purpose of justifying strategies for the optimal regulation of the economic dynamics of high-tech products, is the subject of this article.

This article discusses the following issues:

- approaches to the regulation of economic dynamics;

- the principles of self-organization in economic dynamics models;

- model of economic dynamics based on the principles of selforganization; 
- complex model of regulation of economic dynamics and assessment of the possibility of its use at the stages of creating hightech products.

\subsection{Literature Review}

\subsubsection{Development of Tools for Regulating the Economic Dy-} namics of the Creation of High-Tech Products in Russia

The formation of economic dynamics-as an independent branch of the mathematical economy falls on the second half of the XX century (in the works of V.V. Leontiev and F. Ramsey, the authors of the first model of economic dynamics).

In Russia, the systematic application of mathematical methods in the economy has being developed since the early 60 s of the XX century when The Central Economic and Mathematical Institute of the Academy of Sciences of the USSR was established in 1963 The development tools in the field of economic dynamics took place under the guidance of academician L.V. Kantorovich. On the basis of this school, a corresponding subdivision was created within the Siberian branch of the USSR Academy of Sciences. Subsequent work (Romanovskii I., Makarov V., Rubin A., Belenkii V., Znamenskii V.) completed the stage of formation of economic dynamics as such $[6,7,8,9]$.

The results of the analysis showed that, to date, economic dynamics is viewed, on the one hand, as an independent branch of the theoretical mathematical economy $[6,10,11,12,13]$, and on the other, as a part of the emerging high-tech production lifecycle management system within the $\mathrm{R}$ and $\mathrm{D}$ framework for its creation. Subsequent work in the field of economic dynamics allows stating that there is a certain pattern in implementing the stages of the project for the creation of high-tech production. In particular, it was revealed that the statistical distribution of relative volumes of work is a logistic distribution [3]. The logistic model is currently considered to be one of the main economic dynamics standard models of high-tech production $[14,15,16]$. This distribution is often observed in the economy, production and engineering. Discussed are specific methodological approaches and models of development and manufacturing high-tech products [17, 18]. The main aspects of the probabilistic description of creating high-tech products based on the use of a logistic model are disclosed [19]. Among the other problems of self-organization of economic dynamics models of complex systems, the inductive method of selforganization is considered.

However, a wide range of high-tech items, the large number of parameters influencing the high-tech items creation costs, and many other factors necessitate the improvement of the toolkit for regulating the economic dynamics of the creation of such goods in the context of uncertainty of initial data base and their reliability.

\subsubsection{Development of Tools to Regulate the Economic Dynam- ics of High-Tech Products Creation in the World Leading Technological Countries}

Consider in theses brief form methodical approaches to regulating the dynamics of creating high-tech products in the world leading countries.

Boer [20] considered the financial aspects of the process of developing and implementing new technologies, problems and methodological approaches to the implementation of an integrated assessment of various technological solutions and approaches to the selection of optimal among their many.

Langdon, $\mathrm{Ma}$ and $\mathrm{Wu}$ [21] address the application of a flexible development methodology (agile methodology) to accelerate and enhance the effectiveness of innovative developments by increasing the involvement and more effective use of the creative potential of the team.
In Wingate's work [22] the issues of effective application of the project management methodology were considered to ensure higher probability of successful implementation of innovative projects and optimization of resources in the process of their implementation.

Keeley, Walters and Pikkel [23] examined the issues of typologization of innovations and its application in the process of research and development in order to improve their quality and effectively regulate the dynamics of the creation of high technology products. Harris, Villadsen and Koble [24] analyzed the risks associated with the regulatory impact on certain economy branches in the long term, identified threats to economic subjects and proposed ways to identify assess and prevent the possible negative consequences of such impacts.

Ries [25] presented a comprehensive analysis of the numerous aspects that determine the effective implementation of innovative processes, the optimal allocation of resources and the productive organization of activities to improve innovation processes, as well as reduce the risks associated with them.

Christensen [26] conducted a thorough analysis of the real laws that are characteristic of innovative development as an objective historical process and its impact on the activities of economic entities, including the phenomenon of "subversive innovation" and "closing" technologies capable of to have a fatal impact even on enterprises and companies occupying a leading position.

Dodgson, Gann and Salter [27] discussed the problem of effective management of technological innovations, factors determining the probability of successful implementation of innovative technological projects, ways to enhance the dynamics of the creation of innovative high-tech products.

The analysis of these works showed that the main limitations in the use of methodical approaches to regulating the dynamics of the creation of high-tech products in technologically developed countries of the world are:

- sectoral limitations;

- the need to adapt to domestic economic realities;

- focus on any single factor in the creation of high-tech goods and promoting it to the market $[28,29]$;

- difficulties in obtaining source data, etc..

These restrictions significantly complicate the comprehensive assessment of the feasibility of implementing projects for the creation of high-tech products within a given time, especially at risk, including in relation to Russian enterprises [30, 31, 32].

Thus, the models for regulating the economic dynamics of the creation of high-tech production in sufficient measure and from systemic positions have not been considered in the world scientific and technical literature.

\section{Methods}

\subsection{The Principles of Self-Organization in Economic Dynamics Models}

Economic dynamics is a continuous sequence of stages of creating a high-tech product. Characteristics of the main stages of creating high-tech production (the average relative duration of stages and their progress relative to the cost of the project) are given in Table 1. 
Table 1. Characteristics of the main stages of creating high-tech production.

\begin{tabular}{|c|c|c|c|c|}
\hline \multirow{2}{*}{ Characteristic } & \multicolumn{3}{|c|}{ Main stages } \\
\cline { 2 - 5 } & $\begin{array}{c}\text { Stage 1. } \\
\text { RDE }\end{array}$ & $\begin{array}{c}\text { Front End Engineering De- } \\
\text { sign }\end{array}$ & $\begin{array}{c}\text { Stage 3. } \\
\text { Feasibility } \\
\text { study }\end{array}$ & $\begin{array}{c}\text { Stage 4. } \\
\text { Prototyping and test- } \\
\text { ing }\end{array}$ \\
$\begin{array}{c}\text { Relative Stage Dura- } \\
\text { tion }\end{array}$ & $0.05 \ldots 0.07$ & $0.10 \ldots 0.12$ & $0.60 \ldots 0.70$ & $0.70 \ldots 0.76$ \\
\hline Project Progress & $0.12 . .0 .15$ & $0.15 \ldots 0.22$ & $0.30 \ldots 0.35$ & $0.30 \ldots 0.35$ \\
\hline
\end{tabular}

In accordance with these stages, the economic dynamics of the high-tech can be modeled as a multistage self-organization process, based on the following principles:

- multiplicity. i.e. the multiplicity of models of the high-tech economic dynamics having different values of the relative duration of the stage and the volume of work performed;

- external addition, i.e. transformation of high-tech production at each stage of its creation on the basis of the initial data com- ing from the previous stage and in accordance with the criteria of the next stage;

- inconclusive decisions, i.e. choice of an optimal strategy for regulating economic dynamics with sufficient freedom for selecting rational solutions at each stage of high-tech products creating, see Fig.1.

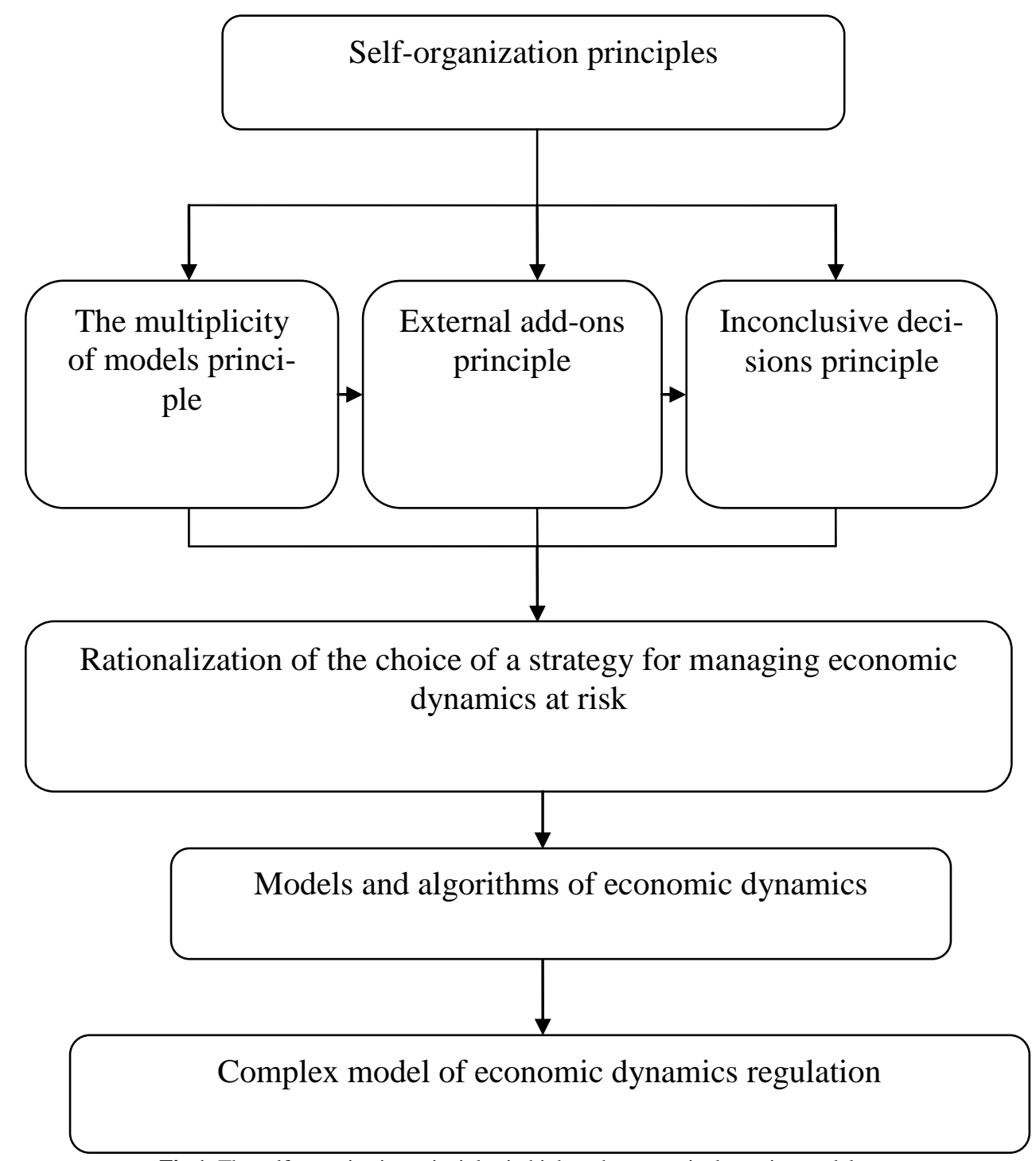

Fig.1. The self-organization principles in high-tech economic dynamics models.

In accordance with these principles, the high-tech economic dynamics formation at each stage is carried out simultaneously in to two opposite directions of self-organization:

- requirements of a subsequent stage to the previous stage (a set of requirements - contour $\{\mathrm{T}\}$ );

- initial data from its present stage going to the next one (a set of source data, or the $\{$ ID $\}$ - contour.)
According to the formulated principles of self-organization, the creation of high-tech production is a multi-stage evolution technology. This means that high-tech should be developed on an incremental principle, so that the developer could use the initial data and knowledge gained when developing former versions of high-tech products. A multi-loop model of the hightech production economic dynamics based on self-organization is shown in Fig.2 


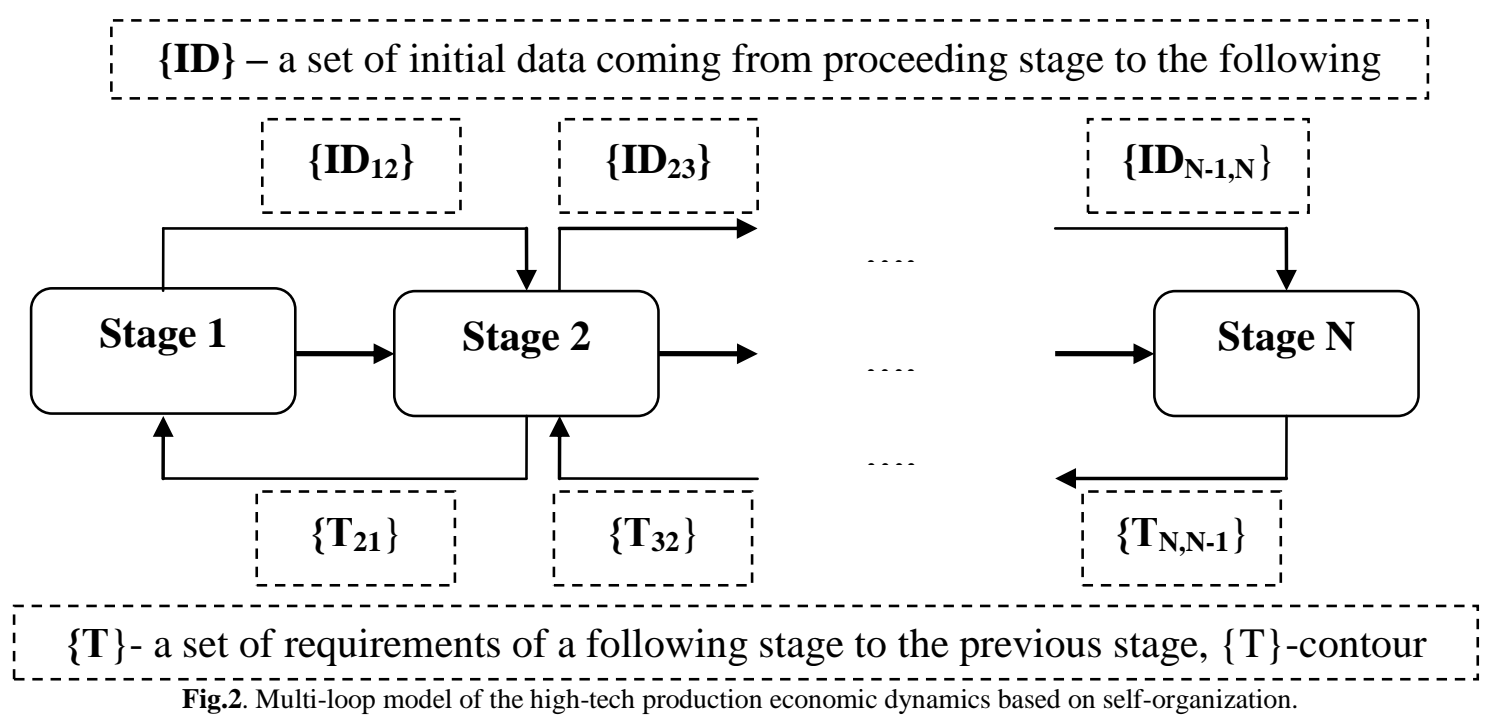

The practice shows that the best success in creating high-tech products depends on a series of "small steps of self-organization," each of which includes a clearly defined result based on the introduction of a set of mature technologies. The beginning steps of this process are the studies aimed at $\mathrm{R}$ and $\mathrm{D}$, and experimental verification of ways and methods of using new scientific knowledge for the purpose of creating high-tech production. In this case, it is possible to make return to the previous successful step in case of failure: before using all the resources allocated for the high tech creations, the developer, founding on the laboratory and bench tests, has the opportunity to correct former mistakes in the project being implemented. Each high-tech production iteration is finalized when the introduction of new scientific knowledge and technologies.

In the practical implementation of the principles of selforganization, the following provisions should be guided:

- specifying requirements for the design of high-tech products that are posted on the time axis;

- modular design with open architecture ideology;

- use of the base product and pre-design allowing taking into account future changes in the project;

Thus, self-organization in the models of the economic dynamics of the high tech products ultimately consists in choosing a rational economic dynamics strategy among the multitude of many, taking into account the multi-stage process of creating high-tech products.

\subsection{Models of Economic Dynamics of High-Tech Prod- ucts Based On the Principles of Self-Organization}

Models of economic dynamics of high-tech products based on the principles of self-organization divided into two types: in conditions of project funding sufficiency or insufficiency.

The general statement of the problems of the first kind is formulated as follows:

- Given: the agreed terms of the project, the cost of the project in stages and the full cost of the entire project, the set of initial data and requirements for work at each stage of the project;

- The task is to determine a rational strategy for regulating economic dynamics, both at each stage of creating a high-tech product, and its overall cost, ensuring the maximum chance of project implementation:

$$
\begin{aligned}
& P\left(S^{*}, t\right) \rightarrow \underset{S \in\{Z\}}{\arg \max } P\left[S_{n}\left(\left\{I D_{n}\right\},\left\{T_{n}\right\}\right), t, C\right], \\
& C \leq C_{p r}, C=\sum_{n=1}^{N} C_{n}, 0 \leq t \leq T,
\end{aligned}
$$

where $P\left(S^{*}, t\right)$ is the probability of project completion at a given time $\mathrm{t} ; \mathrm{S}^{*}$ stands for optimal strategy for regulating economic dynamics; $\{\mathrm{Z}\}-; \mathrm{Cn}, \boldsymbol{C}_{\boldsymbol{p} r}$ - project cost at n-stage and the budget cost of the whole project; $\{\mathrm{IDn}\},\{\mathrm{Tn}\}-$ set of initial data and requirements at the nth stage of project implementation; $\mathrm{T}$ is the agreed date of the project completion.

The general statement of the problems of the second kind is formulated as follows:

- Given: the total cost of the project stages, the significance of each of them:

- The task is to find such a distribution, taking in account a limited financial resource, for the stages of creating high-tech products (or components of high-tech production) in order to implement the project in the most compliance with the requirements of the customer.

Formulation of this problem is further considered for two variants of the project implementation: the first one - all stages of creating high-tech products are dependent on each other; i.e. the execution of the next stage is impossible without the execution of the previous stage; the second option is: all stages of the high-tech products creation are relatively independent and those products can be produced independently of each other.

In accordance with the above provisions, the following probabilistic and cost models of economic dynamics of high-tech production are considered.

\subsection{Probabilistic Models of Economic Dynamics}

\subsubsection{Estimating the Probability of the Project Completion in} Time

The basis of the logistic model for the probabilistic description of creating high-tech products is the dependence of costs on maintaining the lifecycle of the product from the intensity of its implementation:

$C(t)=C_{p r}\left(\frac{t}{T}\right)^{a} \exp \left[a\left(1-\frac{1}{T}\right)\right], 0<t \leq T$,

where $C(t)$ is the project cost at time point t; $C_{p r}$ is the total project cost; $\mathrm{T}$ is agreed terms of the project; $\mathrm{a}>0$ is the intensity of project implementation.

According to this model, the project costs increases monotonically from zero to the value of $C_{p r}$ (at $t=T$ ). The character of the $\mathrm{C}(\mathrm{t}$ ) dependence is determined by the a parameter. The dependence (2) can be used to estimate the probability of a project to be complet- 
ed in t-time, when accepted $C_{p r}=1$, and we also consider the maximum $T_{\max }$ duration for the project instead of time T. Then the expression for the probability of the project of the $\mathrm{Q}<\mathrm{t}$-time duration has the following form:

$$
p(t)=P(Q<t)\left(\frac{t}{T_{\max }}\right)^{a} \exp \left[a\left(1-\frac{t}{T_{\max }}\right)\right], 0<t \leq T_{\max } .
$$

where $p(t)$ is the probability of completing the project in t-time, while $\mathrm{Q}$ is the current project timing.

In this model, the main parameter regulating economic dynamics (the "regulator") is the project intensity performance. Since the determination of the a parameter, as well as the maximum time of project execution $T_{\max }$ based on expert data and high-tech production design statistics, is a problematic task (in practice, it is possible that even with the maximum possible time a project may be not completed), it seems reasonable to use a simpler model of economic dynamics, presented below.

\subsubsection{Estimating the Likelihood of Project Implementation} Taking Into Account the Productivity of Project Developers

In this model, the pace of completion of the scope of work under the project is proportional to the remaining work and the project developers productivity. This assumption is consistent with the of high-tech production design practice. If the relative amount of work performed is presented as a probability of project implementation, then the economic dynamics can be described by the following expression:

$$
\frac{d p(t)}{d t}=k a(t)(1-p(t))
$$

where $k>0$ is the proportionality factor.

Under the initial condition $p(t=0)=p_{0}$, the solution of this equation has the following form:

$$
p(t)=\left(1-\left(1-p_{0}\right)\right) \exp \left(-\int_{0}^{t} k a(t) d t\right)
$$

where $p_{0}$ is the initial level of development of the project for a high-tech product creation.

In this logistic function, the $a(t)$ parameter from the probability point of view characterizes the intensity of the project and is related to the labor productivity. To determine the $a(t)$ parameter, we can use The Cobb-Douglas Production Function describing the production activity of the organization designing high-tech products:

$$
Y=A K^{b} S^{1-b}
$$

where $\mathrm{Y}$ is the cost of manufactured products; $\mathrm{K}$ stands for capital assets (buildings, constructions, devices and equipment, technologies, materials) valued in money; $\mathrm{S}$ - compensation of employees (at the R and D stage, labor compensation is a certain part of the cost of the project $C_{p r}$ for the high-tech products creation); b is the elasticity figure characterizing the degree of influence of production factors on output; $A>1$ is the scale factor characterizing the innovation level of the project and its rise in value in comparison with analogues and prototypes.

The success of the project from the economic point of view is determined by its profitability:
$R=\frac{Y}{C_{p r}}$

The higher the profitability of the project, the more successful the project is completed. If $\mathrm{R}<1$, then from the economic point of view, the project is unprofitable, and its implementation can not be recognized as successful. Therefore, to assess the pace of the project, we use an expression that takes into account the current profitability of the project:

$a=\frac{d Y}{C d t}=b m \frac{Y}{C}$

where $m$ is the rate of change in production assets.

From the expression (8) it follows that with the increase in the qualification level of the personnel of the project organization, the volume and cost of production assets, the profitability of the project raises labor productivity, and hence the probability of successful implementation of the project in time. For a loss-making project, the probability of its successful implementation within a given time will always be less than one.

\subsubsection{Estimate of Probability of Project Execution with Maxi- mum Profitability}

In this model, an estimate of the $p(T)$ probability of a project to create high-tech production with a given probability over time $T p(T ; a) \geq p(T)$ with the fixed budget of $\mathrm{C}$ is achieved on the basis of maximum profitability:

$$
R(b, w, p(t)) \rightarrow \max _{b, w}
$$

where $\mathrm{w}$ is the share of the project budget which comes from the remuneration of scientific and engineering personnel, who carry out the main work on the creation of high-tech production.

The solution of formulated problem can be found using the methods of nonlinear programming. To solve this problem in practice, it is necessary to find an explicit relationship between the remuneration and the project regulation parameters. In order to solve this problem, in practice, it is necessary to find a clear relation between the remuneration and the parameters in order to exclude the dependence of the task on the number of employees of the project organization $\mathrm{N}$; this makes possible to use specific indicators, $\frac{C}{N}, \frac{K}{N}, \frac{Y}{N}$ that do not change the essence and the result of the solution of the problem and project regulation.

In practice, there is often a situation where the achievement of the required technical specifications for high-tech production requires additional time, new materials, equipment and technology. The influence of these factors can be taken into account by adjusting the project cost, Cpr, and the project intensity $\boldsymbol{a}$-parameter.

\subsection{Cost Models of Economic Dynamics}

In the process of creating high-tech production, there is often a situation where real financing is significantly less than planned, for one reason or another. In this case, high-tech developers need to solve the problem of allocating a limited amount of financial resources for the stages of creating high-tech products (or their components) [33].

The general mathematical statement of this task is the following: - Known are: $\mathrm{C}(\mathrm{C}=\mathrm{C} 1, \mathrm{C} 2, \ldots, \mathrm{CN})$ - a set of costs for $\mathrm{N}$ stages of a high-tech product creation; yi - is the importance, or significance, coefficient for each stage of the creation, equal to the relative cost of performing the stage: 


$$
y_{i}=\frac{C_{i}}{\sum_{i=1}^{N} C_{i} \quad(i=\overline{1, N}) .}
$$

In the course of the project, the actual amount of funding appeared less than the planned one.

$$
C_{F} \leq C_{P}=\sum_{i=1}^{N} C_{i}
$$

- The task is: find such a distribution of the allocated amount of financial resources, so that all work on the creation of high-tech production was carried out in full and in the required amount of time.

In the conditions of insufficient financing of a project on creation of high-tech product, two strategic models of economic dynamics regulation are considered below.

\subsection{Model of Economic Dynamics for the Interrelated Stages of Creating High-Tech Products}

In this case, the optimal strategy $\mathrm{S}^{*}$ for regulating the economic dynamics of high-tech production is established on the basis of maximizing the next objective function:

$$
\begin{aligned}
& S^{*}\left(x_{1}, x_{2}, \ldots x_{N}\right) \Rightarrow \max \sum_{i=1}^{\mathrm{N}} y_{i} x_{i} \\
& \sum_{i=1}^{\mathrm{N}} y_{i} x_{i} \leq C_{F}
\end{aligned}
$$

where yi is the realized estimated cost of the project at a given level of its financing; $x i=(1$ if the $i$-th stage of the project is carried out at a given level of funding).

The search for an optimal strategy for regulating economic dynamics reduces to determining the values of the Boolean variables $\mathrm{x}_{\mathrm{i}}\left(\mathrm{x}_{1}, \mathrm{x}_{2}, \ldots, \mathrm{x}_{\mathrm{N}}\right)$ at which the maximum of the objective function (11) is reached under the condition (12). The solution of this problem can be found using some type of a search tree algorithm. To do this, all stages of the project are sorted in order of importance: $y_{1} \geq y_{2} \geq \ldots \geq y_{N}$. Then each $x i$ variable, starting at $x 1$, is sequentially assigned the value " 1 " until the condition (12) is violated. The set of these variables will be the solution of the original problem

\subsection{Model of Economic Dynamics for Independent Stag- es of High-Tech Production Creation}

In this case, the optimal strategy $\mathrm{S}^{*}$ for regulating economic dynamics is set based on minimization of the objective function in the form of the mean square deviation of the actually allocated volume of resources from the planned volume:

$$
S^{*}\left(y_{1}^{*}, y_{2}^{*}, . ., y_{N}^{*}\right) \Rightarrow \min \sum_{i=1}^{N}\left(C_{i}-y_{i}^{*} C_{F}\right)^{2}
$$

under the following restrictions:

$$
y_{i}^{*} \geq 0 ; \quad \sum_{i=1}^{N} y_{i}^{*}=1
$$

where $y^{*}=\left(y_{1}^{*}, y_{2}^{*}, . ., y_{N}^{*}\right)$ is the vector of the allocation of financial resources in new financing conditions.

A new vector of allocation of financial resources is found from the condition of the minimum of the objective func- tion (13) under constraints (14). To do this, we compose the Lagrange function and find its minimum with respect to $y_{i}{ }^{*}$, and 1 :

$$
L\left(y_{1}^{*}, y_{2}^{*}, \ldots, y_{N}^{*} ; l\right)=S^{*}\left(y_{1}^{*}, y_{2}^{*}, \ldots, y_{N}^{*}\right)+l\left(1-\sum_{i=1}^{N} y_{i}^{*}\right)
$$

From the system of equations:

$$
\begin{aligned}
& \left\{\begin{array}{l}
\frac{d L}{d y_{i}}=0 \\
\frac{d L}{d l}=0
\end{array}\right. \\
& \text { We get: } \\
& y_{i}^{*}=\frac{1}{N}+\left(y_{i}-\frac{1}{N}\right) / q
\end{aligned}
$$

where $\mathrm{q}=\mathrm{CF} / \mathrm{CN}$ is the relative funding volume

To fulfill the $y_{i}^{*} \geq 0$ condition, it is necessary that the funding volume is not below the permissible level: $q \geq \max \left(1-N y_{i}\right)=q$

With a funding volume of q below the permissible level, the $y_{i}^{*}$ value will be less than $0, y_{i}^{*}<0$. In this case the problem has no solution for all stages of the project. Therefore, one of them must be eliminated, and the corresponding $y_{i}^{*}$ coefficient is assumed to be zero. Then you need to recalculate the importance factors of the remaining stages of the project.

Here are some concrete examples of using models:

Example 1. Choosing a strategy for regulating economic dynamics based on the optimal allocation of financial resources for R and D to create a new type of high-tech product in conditions of limited funding and determining the minimum permissible level of $\mathrm{R}$ and D financing.

As a rule, technical specifications for R and D suppose a step-bystep implementation of a number of specific tasks, for example: analysis of world experience in creating high-tech products; conducting patent research; development of proposals on promising directions of research; development of Engineering Change Proposals (ECP) for introduction to new types of high-tech production; development of experimental (breadboard) products of hightech production, etc. To fulfill all the above tasks and achieve the $\mathrm{R}$ and $\mathrm{D}$ objectives, the required financial resources volumes for both the whole $\mathrm{R}$ and $\mathrm{D}$ and each of its specific tasks are justified. If the finance volume comes much lower than planned there is a need for efficient use of allocated funds for all tasks of R and D in the fullest volume and in the required time.

The results of solving this problem using the above models are presented in Table 2 . 
Table 2. The solution.

\begin{tabular}{|c|c|c|c|c|c|}
\hline \multirow{3}{*}{$\begin{array}{l}\text { The share of the } \\
\text { required volume of } \\
\text { financial support, q }\end{array}$} & \multicolumn{5}{|c|}{ The importance of the task factor } \\
\hline & $\begin{array}{l}\text { Analysis of the world } \\
\text { experience in creating } \\
\text { high-tech products }\end{array}$ & $\begin{array}{l}\text { Development of } \\
\text { research direction } \\
\text { proposals }\end{array}$ & $\begin{array}{c}\text { Patent } \\
\text { research }\end{array}$ & $\begin{array}{l}\text { Development of proposals } \\
\text { for the implementation of } \\
\text { the results }\end{array}$ & $\begin{array}{l}\text { Development of experimental, } \\
\text { or "breadboard", products of } \\
\text { high-tech production }\end{array}$ \\
\hline & A & $\mathrm{B}$ & $\mathrm{C}$ & $\mathrm{D}$ & $\mathrm{E}$ \\
\hline $\mathbf{1 , 0}$ & 0,1 & 0,3 & 0,1 & 0,2 & 0,3 \\
\hline 0,9 & 0,08 & 0,32 & 0,09 & 0,2 & 0,31 \\
\hline 0,8 & 0,06 & 0,31 & 0,09 & 0,22 & 0,32 \\
\hline 0,7 & 0,04 & 0,32 & 0,11 & 0,22 & 0,33 \\
\hline 0,6 & 0,01 & 0,32 & 0,11 & 0,22 & 0,34 \\
\hline 0,5 & 0 & 0,33 & 0,12 & 0,21 & 0,34 \\
\hline 0,4 & 0 & 0,43 & 0,02 & 0,2 & 0,35 \\
\hline $\mathbf{0 , 3}$ & 0 & 0,53 & 0 & 0,2 & 0,27 \\
\hline 0,2 & 0 & 0 & 0 & 1,0 & 0 \\
\hline 0,1 & 1,0 & 0 & 0 & 0 & 0 \\
\hline
\end{tabular}

From the data given in Table 2, it follows that the ultimate permissible minimum funding level for $\mathrm{R}$ and $\mathrm{D}$ is $\mathrm{q}=0.6$. At the same time, the development of all $\mathrm{R}$ and $\mathrm{D}$ tasks can be carried out, in varying degrees. At $\mathrm{q}<0.6$, simultaneous development of only problems $\mathrm{B}, \mathrm{C}, \mathrm{D}, \mathrm{E}$ is possible. This funding capacity is maintained up to the $q>0$,3level of financing. At $0.2<q<0.3$, only problems B, D, E can be simultaneously developed, and for $\mathrm{q}=$ 0.2 it is only A.

The presented strategy of economic dynamics regulation based on the of financial resources allocation algorithm gives the single decision which is optimum by criterion of a minimum square deviation of the allocated resources compared to the planned $\mathrm{R}$ and $\mathrm{D}$ as a whole.

Example 2. The choice of a strategy for regulating economic dynamics based on the optimal allocation of financial resources for the development of an experimental, breadboard, high-tech product and the definition of the minimum permissible level of its financing.

The results of the calculations are given in Table 3 .

Table 3. The calculation results.

\begin{tabular}{c|c|c|c|c|c|c|c}
\hline \multirow{2}{*}{ Share of required financing, q } & \multicolumn{7}{c}{ The importance factors of the high-tech production components (HTC) } \\
\cline { 2 - 8 } & HTC-1 & HTC-2 & HTC-3 & HTC-4 & HTC-5 & HTC-6 & HTC-7 \\
\hline & A & B & C & D & E & F & G \\
\hline $\mathbf{1 , 0}$ & 0,1 & 0,2 & 0,2 & 0,1 & 0,1 & 0,2 & 0,1 \\
\hline $\mathbf{0 , 9}$ & 0,07 & 0,21 & 0,22 & 0,13 & 0,07 & 0,22 & 0,08 \\
\hline $\mathbf{0 , 8}$ & 0,06 & 0,22 & 0,2 & 0,14 & 0,07 & 0,24 & 0,07 \\
\hline $\mathbf{0 , 7}$ & 0,04 & 0,23 & 0,21 & 0,15 & 0,06 & 0,25 & 0,06 \\
\hline $\mathbf{0 , 6}$ & 0 & 0,24 & 0,22 & 0,17 & 0,06 & 0,25 & 0,06 \\
\hline $\mathbf{0 , 5}$ & 0 & 0,25 & 0,22 & 0,16 & 0,06 & 0,25 & 0,06 \\
\hline $\mathbf{0 , 4}$ & 0 & 0,26, & 0,24 & 0,15 & 0,05 & 0,25 & 0,05 \\
\hline $\mathbf{0 , 3}$ & 0 & 0,35 & 0,20 & 0 & 0 & 0,45 & 0 \\
\hline $\mathbf{0 , 2}$ & 0 & 0 & 0,50 & 0 & 0 & 0,50 & 0 \\
\hline $\mathbf{0 , 1}$ & 1,0 & 0 & 0 & 1,0 & 1,0 & 0 & 0 \\
\hline
\end{tabular}

From the data given in Table 2, it follows that the ultimate permissible minimum funding level for $\mathrm{R}$ and $\mathrm{D}$ is $\mathrm{q}=0.6$. At the same time, development, in varying degrees, of all components of hightech products can be carried out. When q <0.6, only B, C, D, E, F, $\mathrm{G}$ can be simultaneously developed. This funding capacity is maintained up to the level of financing. At $0.2<\mathrm{q}<0.3$, only B, C and $\mathrm{F}$ can be created simultaneously, and for $\mathrm{q}=0.2$ only $\mathrm{C}$ and $\mathrm{F}$. The calculation method based on the above models of regulation of economic dynamics is implemented on a computer in the integrated application development environment Delphi 7 in the form of a software analytical complex for Windows and Linux operating systems. $t$ can be used to justify the required financial resources for planning and practical implementation of complex activities on creation of the high-tech production.

\subsection{Complex Model of Economic Dynamics Regulation}

Taking into account the considered features of the probabilistic and cost models used in Russia and the leading world countries, a comprehensive model for regulating the economic dynamics of high-tech production based on the principles of self-organization is proposed (Fig.3)

The complex model is based on individual models that allow determining:

- the probability of execution of the project within the specified time, $(\mathrm{p}(\mathrm{T})$;
- the probability of completing the project based on the productivity of project developers $(\mathrm{p}(\mathrm{a}))$;

- probability of project execution with maximum profitability (p(Rmax));

- optimal strategy for regulating economic dynamics for independent and interrelated stages of creating high-tech production ( $\left.\mathrm{S}^{*}\right)$.

Taking into account the $\mathrm{p}(\mathrm{T}), \mathrm{p}(\mathrm{a}), \mathrm{p}(\mathrm{Rmax}), \mathrm{S}^{*}$ controls, $\mathrm{S}^{*}$, an optimal strategy for the economic dynamics of high-tech production is selected, ensuring rational use of budgetary funds, minimizing risks and time for creating high-tech production. 


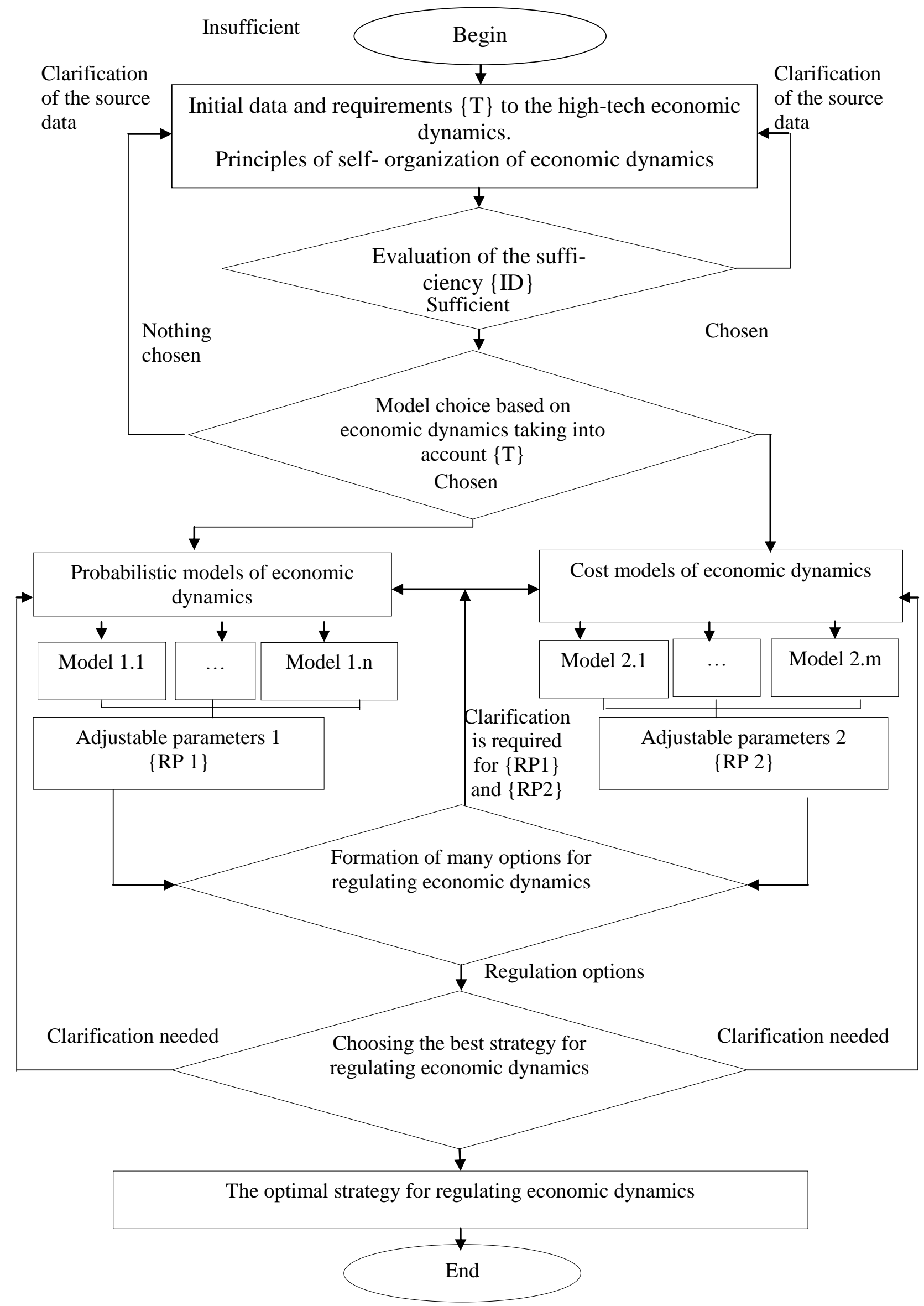

Fig.3. Complex model of regulation of high-tech products economic dynamics. 
The proposed integrated model of regulation of economic dynamics is aimed at the feasibility study of the required values of indicators of high-tech products and can find wide application in various sectors of the Russian and world economy.

\section{Results}

In the article various regulation models of high-tech economic dynamics of production, used in Russia and the leading world countries are considered. It is stated that the existing models are very fragmented, rely on various initial data and do not allow to give a comprehensive assessment of the feasibility of performing $\mathrm{R}$ and $\mathrm{D}$ to create high-tech production for a given time, especially at risk.

A number of high-tech features of the creation is stated, including: the uniqueness of development of the most important technologies; high degree of technological risk; absence of prototypes (analogue products); a relatively unstable level of development of the necessary technological base; the universal nature of most of the technologies used which have prospects for dual purpose.

The types of risks that must be taken into account when selecting a model for regulating the economic dynamics of high-tech production are defined; the main ones of which are:

- financial and economic risk: the probability of lack of funding the of high-tech products development, and excess of actual costs over budgeted ones;

- scientific and technology risk (the probability of a nonfulfilment by high-tech developers of technology requirements, technology tasks for research and development work and the termination of works for scientific and technology reasons);

- industrial and technological risk (associated with the aging of fixed production assets, loss of technology etc.)

Taking into account the stated features and risk factors, models for the regulation of economic dynamics of high-tech production based on the principles of self-organization are suggested, including:

- models based on the probability of project execution (probabilistic models), including:

a) done in time;

b) taking into account the productivity of the project developers;

c) maximum profitability;

- models that take into account the risk of underfinancing the project, for the interconnected and independent stages of creating high-tech production (the cost models).

Practical examples of the use of models are given.

The developed complex model of economic dynamics regulation in the high-tech production allows choosing the necessary type of model under risk conditions and corresponding regulation parameters.

Application of the proposed models makes it possible to carry out a technical and economic assessment of options for creating hightech production and to choose options that ensure the rational use of budget funds allocated for these purposes with maximum efficiency of project implementation in risk.

\section{Discussion}

In modern scientific studies the economic dynamics is considered mostly as an independent branch of theoretical mathematical economics and rarely as part of an emerging system of lifecycle management of high-tech R and d for its creation. However, the features and risks of creating high-tech production are not fully taken into account $[34,35]$. That is why in this article it was necessary to emphasize and explore the economic dynamics as a part of the lifecycle management system for creating high-tech products. The subject and the main object of this article is the identification and study of the regularities of the flow in time of the economic processes on creating high-tech production, taking into account the above-mentioned features and risk factors, with the aim of justifying and selecting the optimal strategy for regulating economic dynamics.

This article discusses the following issues:

- theoretical and methodical approaches to regulating the economic dynamics of high-tech production, used in Russia and the leading foreign countries;

- the principles of self-organization in economic dynamics models;

- models of economic dynamics based on the principles of selforganization; ;

- A complex model of economic dynamics regulation and assessment of the possibility of its use at the stages of creating high-tech products.

It is stated that with the optimal regulation of economic dynamics it is necessary to take into account the following provisions:

- the creation of high-tech production is a multi-stage process of gradual improvement;

- high-tech products should be developed on an incremental principle, so that the developer could use the initial data and knowledge gained when developing former versions of high-tech products.

- The practice shows that the best success in creating high-tech products depends on a series of "small steps of self-organization," each of which includes a clearly defined result based on the introduction of a set of mature technologies;

- the possibility to return to the previous successful stage (step) in case of failure: in this case, before using all the resources allocated for the creation of high-tech production, the developer, based on the results of lab studies and bench tests, has the opportunity to correct available miscalculations and errors in the project being implemented;

- each high-tech production iteration is finalized when the introduction of new scientific knowledge and technologies. Additional functions can be also welcome to the iteration as well.

In practice, the implementation of economic dynamics, the following guidelines should be followed:

- specifications for the projected high-tech products spread along the time axis;

- modular design with open architecture ideology;

- use of the basic product and the pre-design, taking into account the future possible changes in the project;;

- maximum use of available scientific and technological and industrial-technological backlogs ("mature" scientific knowledge and production technologies, unified modules, blocks, standard technical solutions, materials and substances).

The need to take into account the above provisions in the planning and practical implementation of economic dynamics is caused by a number of circumstances; and, above all, the practical need for carrying out feasibility studies of economic dynamics in conditions of a minimum amount of initial data.

\section{Conclusion}

In this article, the process of creating high-tech is presented as a multi-stage multi-loop process, based on the formulated principles of self-organization:

- multiplicity (i.e. the multiplicity of models of the high-tech economic dynamics posses different values of the relative duration of the stage and the volume of work performed);

- transformation of high-tech production at each stage of its creation on the basis of the initial data coming from the lower stage and in accordance with the requirements. and - the criteria imposed by the higher stage (the principle of external supplementation); 
- multi-stage selection of the optimal strategy for the regulation of economic dynamics with sufficient freedom of choice of rational solutions at each previous stage (the principle of nonterminal decision decision.)

The main principle of further improvement of the methodological tools for regulating the economic dynamics of high-tech production should be to achieve a minimum costs and / or maximum efficiency at given costs.

\section{Acknowledgements}

This paper was financially supported by the Ministry of Education and Science of the Russian Federation on the project No.26.1146.2017/4.6 «Development of mathematical methods to forecast efficiency of using space services in the national economy».

\section{References}

[1] V.M. Burenok, G.A. Lavrinov, A.G. Podolsky, Otsenka stoimostnech pokazatelei vysokotekhnologichnoi produktsii [Estimation of cost indexes of high-tech products], Publishing Group "Border", Moscow, 2012.

[2] G. Villani, Valuation of RandD Investment Opportunities with the Threat of Competitors Entry in Real Option Analysis, Computational Economics 43(3) (2014) 331-355.

[3] E. Khrustalev, O. Khrustalev, Modelirovanie zhiznennogo tsikla programmy sozdania naukoemkoi produktsii [Simulation of creating High technology products of theprogram life cycle], Ekonomicheskiy analiz: teoria i praktika [Economic analysis: theory and practice] 16(271) (2012) 2-12. https://cyberleninka.ru/article/n/modelirovanie-zhiznennogo-tsiklaprogrammy-sozdaniya-naukoemkoy-produktsii. Accessed July 2, 2018.

[4] Ely, P. van Zwanenberg, A. Stirling, Broadening out and opening up technology assessment: Approaches to enhance international development, co-ordination and democratization, Research Policy 43(3) (2014) 505-518

[5] G. Wei, X. Zhao, H. Wang, R. Lin, An Approach to Potential Evaluation of Emerging Technology Commercialization with Intuitionistic Trapezoidal Fuzzy, Journal of Convergence Information Technology 8(1) (2013) 588-597.

[6] V. Belenkii, Optimizatsionnye modeli economicheskoi dinamiki: poniatiinyii apparat: odnomerniemodeli [Optimization models of economic dynamics: the conceptual apparatus: one-dimensional models], Nauka, Moscow, 2007.

[7] V. Znamenskii, Strukturirovanie ekonomicheskoi sistemy v tseliakh upravlenia ekonomicheskoi dinamikoi [Structuring of the economic system for the management of economic dynamics], Elektronnyi nauchnyi zhurnal: upravlenie ekonomicheskimi sistemami [Electronic scientific journal: Management of economic systems] 12(48) (2012) 101-112. https://cyberleninka.ru/article/n/strukturirovanieekonomicheskoy-sistemy-v-tselyah-upravleniya-ekonomicheskoydinamikoy. Accessed July 2, 2018.

[8] V. Znamenskii, Dinamika ekonomicheskikh system i tsikly [The dynamics of economic systems and cycles], Elektronnyi nauchnyi zhurnal: upravlenie ekonomicheskimi sistemami [Electronic scientific journal: Management of economic systems] 9 (2012) 31-49. https://cyberleninka.ru/article/n/dinamika-ekonomicheskih-sistemi-tsikly. Accessed July 2, 2018.

[9] Kamae, T. Sugimoto, K. Yamabe, Value-Based Pricing Scheme for new Technology in Consideration of Cost-Effectiveness Dominance to the Control, Value in Health 18(7) (2015) A732.

[10] Voronov, Metodologiia geopoliticheskogo analiza teoreticheskogo i metateoreticheskogo urovnei $\mathrm{v}$ kontekste vliianiia na economicheskuiu dinamiku natsionalnykh ekonomicheskikh sistem [The Methodology of geopolitical analysis, theoretical and metatheoretic levels in the context of the impact on economic dynamics of national economic systems], Perspektivy nauki [Prospects of science] 4(67) (2015) 154-157.

[11] V. Znamenskii, E. Vagina, Fenomeny, okazyvaiushche otritsatelnoe vliianie na ekonomicheskuiu dinamiku [Phenomena that have a negative impact on economic dynamics], Upravlenie riskom [Risk management] 2(66) (2013) 8-17.
[12] Kopoteva, K modelirovaniiu vklada nauchno-tekhnicheskogo progressa $\mathrm{v}$ ekonomicheskuiu dinamiku [Modeling of the contribution of scientific and technological progress in economic dynamics], Fundamentalnye issledovaniia [Basic research] 7 (2008) 107-108.

[13] M. Calderon, The Pillars of Cost-Effectiveness: A Practical Guideline for New Technology Cost-Effective Decision-Making, Value in Health 18(3) (2015) A102.

[14] A.M. Batkovskiy, A.V. Leonov, A.Yu. Pronin, E.G. Semenova, A.V. Fomina, Models of Economic Evaluation of High-Tech Products, Indian Journal of Science and Technology 9(27) (2016) 230241. DOI: $10.17485 /$ ijst/2016/v9i28/97660.

[15] P. Steffens, E. Douglas, Valuing technology investments: use real options thinking but forget real options valuation, International Journal of Technoentrepreneurship 1(1) (2007) 58-77.

[16] C. Ullrich, Valuation of IT Investments Using Real Options Theory, Business and Information Systems Engineering 5(5) (2013) 331341 .

[17] V. Lebedev, K. Lebedev, Matematicheskoe i kompiuternoe modelirovanie economiki [Mathematical and computer modeling of the economy], HVT-Dizain, Moscow, 2002.

[18] L. Leite, J. Teixeira, C. Samanez, Ex-ante economic assessment in incremental RandD projects: technical and development time uncertainties addressed by the real options theory, Pesquisa Operacional 32(3) (2012) 617-642.

[19] K. Bagrinovskii, M. Bendikov, E. Khrustalev, Sovremennye metody upravlenia tekhnologicheskim razvitiem [Modern methods of technological development management], ROSSPEN, Moscow, 2001.

[20] F.P. Boer, The Valuation of Technology: Business and Financial Issues in RandD. Operations Management Series, Wiley, Hoboken, 1999.

[21] M. Langdon, M. Ma, P.C. Wu, Agile Innovation: The Revolutionary Approach to Accelerate Success, Inspire Engagement, and Ignite Creativity, Wiley, Hoboken, 2014.

[22] M. Wingate, Project Management for Research and Development: Guiding Innovation for Positive RandD Outcomes Series: Best Practices and Advances in Program Management, CRC Press, 2013.

[23] L. Keeley, H. Walters, R. Pikkel, Ten Types of Innovation: The Discipline of Building Breakthroughs, Wiley, Hoboken, 2013.

[24] D. Harris, B. Villadsen, L. Koble, Risk and Return for Regulated Industries, Elsevier Academic Press, 2017.

[25] E. Ries, The Lean Startup: How Today's Entrepreneurs Use Continuous Innovation to Create Radically Successful Businesses, Crown Business, 2011.

[26] C.M. Christensen, The innovator's dilemma, Harvard Business Review Press, Boston, 2016.

[27] M. Dodgson, D.M. Gann, A. Salter, The Management of Technological Innovation: Strategy and Practice, Oxford University Press, Oxford, 2008.

[28] J. Tidd, J. Bessant, Managing Innovation: Integrating Technological. Market and Organizational Change, Wiley, Hoboken, 2013.

[29] M. Calderon,O.A. Salvatierra, R. Roording, The New Technology Cost-Effectiveness Checklist: Introducing a Practical Guideline for the Selection of Health Technologies, Value in Health 18(7) (2015) A569.

[30] Matveev, D. Novikov, A.V. Tsvetkov, Modeli i metody upravlenia portfeliami proektov [Models and methods of project portfolio management], PMSOFT, Moscow, 2005.

[31] J. Cho, J. Lee, Development of a new technology product evaluation model for assessing commercialization opportunities using Delphi method and fuzzy AHP approach, Expert Systems with Applications 40(13) (2013) 5314-5330.

[32] W. Woertman, G. van De Wetering, E. Adang, Cost-Effectiveness on a Local Level: Whether and When to Adopt a New Technology, Medical Decision Making 34(3) (2013) 379-386.

[33] A.M. Batkovskiy, M.A. Batkovskiy, E.G. Semenova, A.V. Fomina, E.Yu. Khrustalev, Linguistic Analysis of High-Tech Production Complex, Mediterranean Journal of Social Sciences 6(4) 2015 130139. DOI: $10.5901 / \mathrm{mjss} .2015 . v 6 n 4 s 4 p 130$.

[34] V. Klochkov, A. Dutov, Model upravlenia prikladnymi issledovaniami i razrabotkami v naukoemkoi promyshlennosti [Management model applied research and development in the knowledgebased industry], Ekonomicheskiy analiz: teoria i praktika [Economic analysis: theory and practice] 35(290) (2012) 9-1.

[35] B. Amendola, Cost effectiveness in new technologies, Reports of Practical Oncology and Radiotherapy 18(1) (2013) 9-11. 